ISSN 1392-3196 / e-ISSN 2335-8947

Zemdirbyste-Agriculture, vol. 106, No. 1 (2019), p. 53-58

DOI 10.13080/z-a.2019.106.007

\title{
The effects of water steam on weeds and fungal diseases in the stands of onion
}

\author{
Regina VASINAUSKIENE ${ }^{1}$, Zita BRAZIENE² ${ }^{2}$, Dovile AVIŽIENYTE் ${ }^{2}$ \\ ${ }^{1}$ Vytautas Magnus University Agriculture Academy \\ Studentų 11, Akademija, Kaunas distr., Lithuania \\ E-mail: regina.vasinauskiene@asu.lt \\ ${ }^{2}$ Rumokai Research Station, Lithuanian Research Centre for Agriculture and Forestry \\ Klausučių 20, Klausučiai, Vilkaviškis distr., Lithuania
}

\begin{abstract}
The experiment was conducted in the fields of farmers in Kaunas (in 2012), Vilkaviškis (in 2013) and Rietavas (in 2014) districts, Lithuania. The aim of the study was to ascertain the effects of water steam as a weed and fungal disease control method in the common onion (Allium cepa L.) stand. The trials were carried out according to the following design: 1) weeds were hand-weeded three times: the first hand-weeding was performed after mass emergence of weeds, 9-11 days after planting of onions; the second and third hand-weeding operations were carried out after emergence of weeds at a 2-3 leaf growth stage of weeds; 2) thermal weed control using water steam was carried out twice per growing season with the duration of weeds and onions exposure to steam of 2 seconds; thermal weed control was applied on the entire experimental plot, i.e. all over the plot, without protection of onion plants against exposure to steam; 3) thermal weed control using water steam was carried out twice per growing season with the duration of weed exposure to steam of 2 seconds. Thermal weed control was applied only in the inter-rows at a seedling stage of weeds. The impact of water steam on the onion bulbs was partial.

The findings of the current study suggest that the application of water steam all over the trial plots, twice per growing season gave the most effective control of weeds in the stands of onion. Water steam treatment was found to reduce the occurrence of fungal diseases in the onion stand. The severity of downy mildew in the plots treated with water steam decreased by 52.5-739\%, compared with the control plots. The steam treatment all over the trial plots reduced the severity of white rot of onion by $43.5-46.9 \%$. Steaming all over the plots diminished the onion neck rot infection level on onion plants by $68.0-86.1 \%$, while inter-row steaming reduced the disease pressure by $33.3-83.7 \%$. The yield of common onion bulbs in our study ranged from 4.06 to $5.41 \mathrm{~kg} \mathrm{~m}^{-2}$. A statistically significantly higher yield of onion bulbs was produced in the treatment where steaming had been applied all over the plots compared with the hand-weeded plots.
\end{abstract}

Key words: Allium cepa, mildew, neck rot, onion yield, water steam, weeds, white rot.

\section{Introduction}

A major problem that organic farmers face is weed management (Edesi et al., 2012). In most organic farms, weeds are controlled mechanically (Jodaugienė et al., 2008; Van der Weide et al., 2008; Fontanelli et al., 2009; Pannacci, Tei, 2014). Another increasingly used weed control method is thermal weed control. Thermal weed control can be used in various crops (Shrestha et al., 2013; Velička et al., 2016) In different countries, diverse methods of thermal weed control are used in organic farms: flaming (Sivesind et al., 2012), combustion gases (Ulloa et al., 2010; 2012; Datta, Knezevic, 2013), hot foam (Cederlund, Börjesson, 2016), hot water (De Cauwer et al., 2014) and water steam (Melander, Kristensen, 2011; Shrestha et al., 2012; Vidotto et al.,
2013). Researchers have indicated that thermal weed control is more effective than mechanical weed control (Virbickaite et al., 2006; Ascard et al., 2007). However, other researches came up with opposite conclusions (Velička et al., 2016).

Onions are sensitive to weeds. It has been found that $90 \%$ of changes in bulb yield depend on the weed infestation level. The literature data suggest that thermal weed control in the onion crop destroys weeds and increases onion yield (Kerpauskas et al., 2009; Sivesind et al., 2012). Yield increase is influenced by the two factors: non-disturbance of onion root system in the vegetative season and thermal stress, which causes partial injury to the onion neck. In our study we noticed 
a third factor, which is a decrease of fungal diseases in the onion stand.

Fungal diseases in onion are a relevant problem. One of the most devastating diseases of onions is downy mildew (Peronospora destructor (Berk.) Casp. ex Berk.), which occurs annually in the onion production areas. The outbreaks of downy mildew can result in up to 20 $30 \%$ yield losses in the field during the onions growing season. Downy mildew also infects bulb tissue, resulting in bulbs that become soft and shrivelled in storage. It is important to identify factors influencing the occurrence of this disease in order to protect crops and obtain the highest possible onion yield. The inoculum of the downy mildew overwinters in onion bulbs and in the residues of the diseased plants, or as mycelium in the planting material. If the weather is humid, $1 \%$ of infected plants are sufficient to infect the entire crop (Abkhoo, 2012).

White rot of onion (Stromatinia cepivora (Berk.) Whetzel.) also infects onion bulbs. The disease infects whole plants and the yield is lost. Sclerotia remain viable in the soil for several years and can infect healthy plants (Southwood et al., 2015).

Onion neck rot (Botrytis allii Munn., Botrytis cinerea Pers., Botrytis spp.) affects leaves and bulbs of onion (Rasiukevičiūtè et al., 2016). The rots caused by the Botrytis spp. fungi in Lithuania and in the rest of the world result in yield losses ranging from $15-20 \%$ to $50 \%$. The optimal weather conditions for the spread of rots and no use of fungicides cause severe epiphytotics of the disease (Valiuškaitè et al., 2010).

The use of thermal weed control affects not only weeds but also pests, pathogenic microorganisms, as well as disease causal agents of crops. There is very little data about the effect of the thermal control on fungal diseases of plants. The literature data indicate that water steam reduced verticillium and dark leaf and pod spot incidence in winter oilseed rape crop (Marcinkevičienė et al., 2018) and flaming reduced blossom end rot incidence in tomato (Wszelaki et al., 2007).

The current study aimed to determine the effects of water steam used as a thermal control method on weeds and fungal diseases in onions.

\section{Materials and methods}

The sites of field trials. In 2012, field trials were conducted in Kaunas district, Cinkiškiai village on an Epicalcari Endogleyic Cambisol (CM-gln.cap) with a texture of light loam on moderately heavy loam. In 2013, field trials were carried out in Vilkaviškis district, Klausučiai village on a Haplic Epigleyic Luvisol ( $L V$-glp. $h a$ ) with a texture of sandy loam on light sandy loam. In 2014, field trials were done in Rietavas district, Sauslaukio village on an Endogleyic Eutric Planasol (PL-eu.gln) with a texture of light sandy loam on moderately heavy loam. The soils are classified according to WRB (2014). A common onion (Allium cepa L.) cultivar 'Centurion' $\mathrm{F}_{1}$ was grown in the field trials. The onions were planted in rows with a $25 \mathrm{~cm}$ distance between rows and a $7 \mathrm{~cm}$ distance between plants. The experiment was laid out in four replications. The plots were arranged in a random order. The size of experimental plot was $21 \mathrm{~m}^{2}$.
The following experimental design was used: 1) manual weed control: weeds were hand-weeded three times; the first hand-weeding was performed after the mass emergence of weeds, 9-11 days after planting of onions; the second and third hand-weeding operations were carried out after emergence of weeds at a 2-3 leaf growth stage of weeds; 2) water steam on entire plots: thermal weed control using water steam was performed twice per growing season with the duration of weed exposure to steam of 2 seconds; thermal weed control was applied on the entire experimental plot, i.e. all over the plots, without the protection of onion plants against the effects of exposure to steam; 3) water steam on inter-rows: thermal weed control using water steam was carried out twice per growing season with the duration of weed exposure to steam of 2 seconds. Thermal weed control was applied only in the inter-rows at a seedling stage of weeds. The impact of water steam on the onion bulbs was partial.

Weeds were counted before each steaming and 5 days after each steaming in four $0.25 \mathrm{~m}^{2}$ spots of each plot. Within the first ten-day period of July, weeds were counted in all treatments, and their air-dry mass was determined.

The following fungal diseases were assessed in the onion stand: downy mildew, white rot and neck rot. The fungal diseases were assessed only in 2013 and 2014.

Disease assessment before harvesting was conducted in 4 spots of each trial plot on 10 plants per row. The infected plants were counted and the disease incidence, expressed in percent, was calculated as follows (Žemès ūkio augalų kenkèjai..., 2002): $\mathrm{P}=\mathrm{n} \times 100 /$ $\mathrm{N}$, where $\mathrm{P}$ is disease incidence, $\%, \mathrm{n}-$ the number of diseased plants, $\mathrm{N}-$ the total number of inspected plants.

Disease severity was calculated according to the following formula: $\mathrm{R}=[\Sigma(\mathrm{n} \times \mathrm{b})] / \mathrm{N}$, where $\Sigma(\mathrm{n} \times \mathrm{b})$ is the number of leaves with the same infection score or percentage and the sum of products of severity value, $\mathrm{N}-$ the total number of leaves scored.

The onions crop was harvested on 10-15 August from four spots of each trial plot from one square meter.

In 2012, the average daily temperature of May and the amount of rainfall were close to the standard climate normal (SCN). June was cool and rainy. The amount of rainfall was 34\% higher than the SCN. July was warmer than usual, and the amount of rainfall exceeded the SCN by 1.5 times. The average daily temperature and the amount of rainfall of the first ten-day period of August were close to the SCN.

In 2013, May was warm; the average daily temperature was $2.7^{\circ} \mathrm{C}$ higher than the SCN. The amount of rainfall was close to the normal. June was warm and dry with an average daily temperature exceeding the SCN by $2.8^{\circ} \mathrm{C}$, whereas the amount of rainfall was 1.6 times lower than the normal. The average daily temperature of July was close to the $\mathrm{SCN}$, and the amount of rainfall was 1.5 times higher than the SCN. The first ten-day period of August was warm with a sufficient amount of rainfall. In 2014, May was moderately warm and rainy. In June, the weather became cooler, with ununusually 
cool third ten-day period when the average daily temperature was by 3 degrees lower than the SCN, while the amount of rainfall was close to the $\mathrm{SCN}$. The average daily temperature of July was $2.5^{\circ} \mathrm{C}$ higher than the SCN, whereas the amount of rainfall was close to the standard climate normal. The first ten-day period of August was warm and dry.

The trial data were statistically processed using the analysis of variance ( $A N O V A$ ) (Raudonius, 2017). The experimental data that did not fit the normal distribution law were transformed using the function $y=\ln x+1$ prior to the statistical evaluation.

\section{Results and discussion}

The predominant broadleaf annual weed species in the onion stand during the trial period were as follows: white goosefoot (Chenopodium album L.), common chickweed (Stellaria media (L.) Vill.), shepherd's purse (Capsella bursa-pastoris (L.) Medik.) and field pennycress (Thlaspi arvense L.). The broadleaf perennial weeds found in the trial plots were as follows: corn thistle (Cirsium arvense L. Scop.) and field sowthistle (Sonchus arvensis $\mathrm{L}$.). The monocot weed species found in the trial plots were as follows: couch grass (Elytrigia repens (L.) Nevski) in 2012-2014 and barnyard grass (Echinochloa crus-galli (L.) P. Beauv.) in 2013-2014.

The number of weeds estimated before the first application of steam was similar in all trial treatments (Table 1). There were found differences in weed counts only between experimental years. Five days after application, steam treatments were shown to reduce the weed counts by $84.9-97.6 \%$.

Table 1. Number of weeds $\mathrm{m}^{-2}$ in the stands of onion

\begin{tabular}{|c|c|c|c|}
\hline Treatment & 2012 & 2013 & 2014 \\
\hline \multicolumn{4}{|c|}{ Before $1^{\text {st }}$ weed control } \\
\hline Manual weed control & 21.3 & 31.7 & 35.2 \\
\hline Water steam on entire plots & 20.8 & 32.8 & 36.9 \\
\hline Water steam on inter-rows & 18.0 & 25.5 & 40.1 \\
\hline $\mathrm{LSD}_{05}$ & 2,32 & 3.41 & 4.15 \\
\hline \multicolumn{4}{|c|}{ After $1^{\text {st }}$ weed control } \\
\hline Manual weed control & 2.0 & 3.5 & 2.8 \\
\hline Water steam on entire plots & 0.5 & 1.0 & 0.9 \\
\hline Water steam on inter-rows & 2.1 & 2.8 & 3.4 \\
\hline $\mathrm{LSD}_{05}$ & 1.37 & 0.89 & 1.02 \\
\hline \multicolumn{4}{|c|}{ Before $2^{\text {nd }}$ weed control } \\
\hline Manual weed control & 46.5 & 37.8 & 25.2 \\
\hline Water steam on entire plots & 26.5 & 17.0 & 18.4 \\
\hline Water steam on inter-rows & 37.2 & 29.8 & 21.7 \\
\hline $\mathrm{LSD}_{05}$ & 4.13 & 5.26 & 3.85 \\
\hline \multicolumn{4}{|c|}{ After $2^{\text {nd }}$ weed control } \\
\hline Manual weed control & 3.5 & 2.2 & 2.1 \\
\hline Water steam entire & 1.8 & 1.2 & 0.9 \\
\hline Water steam inter-rows & 4.8 & 5.0 & 6.2 \\
\hline $\mathrm{LSD}_{05}$ & 0.83 & 0.95 & 0.77 \\
\hline
\end{tabular}

The steam treatment was applied for the second time on 20-25 June. During the second steaming, it was noticed that in 2012 the emergence of weeds was more intensive, while in 2014 it was less intensive compared with the first emergence of weeds. The intensity of weed emergence was found to be associated with the weather conditions. In 2012, the whole month of June was rainy, whereas in 2014 the first half of June was dry. The amount of rainfall during the second and third ten-day periods of this month was close to the standard climate normal; however, the amount of rainfall was unevenly distributed: there were two days with heavy rain and the rest of the period was without rain. Before the second application of steam, the weed counts were significantly lower in the plots treated with water steam, compared with hand-weeded plots. Steam treatment affected not only already emerged weeds but also emerging weeds. Five days after the second application of steam, the weed counts in the steam-treated plots had decreased by $71.4-95.1 \%$.

During both steam treatments, higher weed counts were identified in the plots where steam treatment had been applied only on inter-rows. The weeds that grew in the rows between the onion plants were either not affected by steaming at all or affected only partially.

In order to estimate the efficacy of steaming, weed counts were made and weed air-dry mass was determined one month after the last application of steam (Table 2). In 2012 and 2013, in the trial plots where steam had been applied only in the inter-rows, weed counts were higher than in the plots in which steaming had been applied all over the plots; however, the differences were not significant. The air-dry mass of weeds from the plots where steaming was applied in the inter-rows was statistically significantly higher than in the plots of treatments 1 and 2 in all experimental years.

Table 2. Number of weeds and air-dry mass one month after the last weed control

\begin{tabular}{|c|c|c|c|}
\hline Treatment & 2012 & 2013 & 2014 \\
\hline \multicolumn{4}{|c|}{ Number of weeds $m^{-2}$} \\
\hline Manual weed control & 10.5 & 10.5 & 8.3 \\
\hline Water steam on entire plots & 10.2 & 12.8 & 10.8 \\
\hline Water steam on inter-rows & 12.3 & 14.3 & 7.6 \\
\hline $\mathrm{LSD}_{05}$ & 2.18 & 1.96 & 1.83 \\
\hline \multicolumn{4}{|c|}{ Air-dry mass $\mathrm{g} \mathrm{m}^{-2}$} \\
\hline Manual weed control & 13.10 & 11.77 & 12.90 \\
\hline Water steam on entire plots & 10.38 & 16.00 & 9.95 \\
\hline Water steam on inter-rows & 22.15 & 18.34 & 15.27 \\
\hline $\mathrm{LSD}_{05}$ & 1.82 & 1.73 & 2.18 \\
\hline
\end{tabular}

Steam application as a weed control method in the onions was shown to reduce disease incidence as well. In order to accurately estimate the effects of steaming on onion diseases, we carried out assessments of fungal diseases at the beginning of August, before harvesting in 2013 and 2014. In both experimental years, onion leaves were most severely affected by downy mildew (agent Peronospora destructor Berk. Fr.) (Table 3). The disease affected $15.2-39.9 \%$ of onion leaves and the disease severity ranged from $1.52 \%$ to $10.49 \%$. Onions 
Table 3. Downy mildew incidence and severity in the stands of onion, $\%$

\begin{tabular}{lcccc}
\hline \multirow{2}{*}{\multicolumn{1}{c}{ Treatment }} & \multicolumn{2}{c}{ Incidence } & \multicolumn{2}{c}{ Severity } \\
\cline { 2 - 5 } & 2013 & 2014 & 2013 & 2014 \\
\hline Manual weed control & $39.9 \mathrm{a}$ & $25.1 \mathrm{a}$ & $10.49 \mathrm{a}$ & $5.83 \mathrm{a}$ \\
Water steam on entire plots & $26.0 \mathrm{~b}$ & $15.2 \mathrm{a}$ & $3.79 \mathrm{~b}$ & $1.52 \mathrm{~b}$ \\
Water steam on inter-rows & $29.2 \mathrm{ab}$ & $18.3 \mathrm{a}$ & $4.98 \mathrm{~b}$ & $2.16 \mathrm{~b}$ \\
\hline
\end{tabular}

Note. The differences between the averages of treatments marked by not the same letter $(\mathrm{a}, \mathrm{b})$ are significant $(P<0.05)$.

were more severely affected by downy mildew in 2013 when the weather before harvesting was relatively warm, and the amount of rainfall was high. In both trial years, steam application in the onions significantly reduced the severity of downy mildew. Similar research findings were obtained in the sugar beet stand where steaming was found to significantly reduce the severity of foliar diseases in sugar beet stand (Brazienè, Vasinauskienè, 2016).

Water steam treatment was also found to impact on the severity of fungal diseases on onion bulbs (Table 4). In the hand-weeded plots, the white rot of onion affected $45.6-57.5 \%$ of the total bulbs assessed, whereas where weed control was conducted by applying steam all over the plots, white rot-affected bulbs accounted for $24.2-32.5 \%$ (depending on the trial year). In the treatments where steaming was applied only on the inter-rows, a reduction in the number of white rotaffected bulbs was identified only in 2013. Steaming was also found to affect the spread of onion neck rot. In the plots where steaming had not been applied, onion neck rot-affected bulbs accounted for 7.2-15.3\% (depending on the trial year). Steaming applied all over the plots reduced the neck rot incidence on onions by $68.0-86.1 \%$, the reduction in the neck rot incidence in the inter-row steamed plots amounted to $33.3-83.7 \%$.

Table 4. Severity of fungal diseases on onion bulbs, $\%$

\begin{tabular}{lcccc}
\hline \multirow{2}{*}{ Treatment } & \multicolumn{2}{c}{ White rot } & \multicolumn{2}{c}{ Neck rot } \\
\cline { 2 - 5 } & 2013 & 2014 & 2013 & 2014 \\
\hline Manual weed control & $57.5 \mathrm{a}$ & $45.6 \mathrm{a}$ & $15.3 \mathrm{a}$ & $7.2 \mathrm{a}$ \\
Water steam on entire plots & $32.5 \mathrm{~b}$ & $24.2 \mathrm{~b}$ & $4.9 \mathrm{a}$ & $1.0 \mathrm{~b}$ \\
Water steam on inter-rows & $42.5 \mathrm{ab}$ & $46.3 \mathrm{a}$ & $2.5 \mathrm{a}$ & $4.8 \mathrm{a}$ \\
\hline
\end{tabular}

Note. The differences between the averages of treatments marked by not the same letter $(a, b)$ are significant $(P<0.05)$.

The yield of onion bulbs in our trials ranged from 4.06 to $5.41 \mathrm{~kg} \mathrm{~m}^{-2}$ (Table 5). A statistically significantly higher bulb yield was obtained in the treatment, where steaming had been performed all over plots compared with the hand-weeded plots. This resulted from the fact that soil had not been disturbed and onion roots had not been damaged. Moreover, the documented research findings suggest that steaming applied in the onion stand and the resulting thermal stress activate plant growth and, in turn, increase the yield (Sirvydas, Kerpauskas, 2012).
Table 5. The yield of onion bulbs, $\mathrm{kg} \mathrm{m}^{-2}$

\begin{tabular}{lcccc}
\hline \multicolumn{1}{c}{ Treatment } & 2012 & 2013 & 2014 & Average \\
\hline Manual weed control & 4.30 & 4.49 & 4.13 & 4.42 \\
Water steam on entire plots & 5.41 & 5.21 & 4.40 & 5.01 \\
Water steam on inter-rows & 4.20 & 5.02 & 4.06 & 4.43 \\
LSD $_{05}$ & 0.470 & 0.415 & 0.572 & 0.565 \\
\hline
\end{tabular}

In the plots where steaming had been applied only on the inter-rows, the yield increase was obtained only in 2013. This is likely to be associated with the more abundant mass of weeds in these plots. Statistical analysis showed negative, weak and statistically not significant correlation between these indicators.

\section{Conclusions}

1. Water steam treatment applied in the onion stand was shown to provide effective control of weeds. The data of the assessments carried out 30 days after the last steam treatment suggest that the best weed control was achieved when steam treatment had been applied twice on the entire trial plots. This method proved to be also most effective in reducing air-dry mass of weeds.

2. Steaming treatment against weeds was found to reduce the occurrence of foliar diseases in the onion stand. The severity of downy mildew in the steamtreated plots decreased by $52.5-73.9 \%$ compared with the control treatment.

3. Steaming all over the plots resulted in 43.5$46.9 \%$ reduction in onion white rot severity.

4. Steam treatment on the entire plots decreased the incidence of onion neck rot by $68.0-86.1 \%$ and steaming of inter-rows gave $33.3-83.7 \%$ reduction in the disease incidence.

5. Steaming all over the trial plots enhanced the onion bulb yield by $6.5-16.8 \%$.

Received 03052018

Accepted 15102018

\section{References}

1. Abkhoo J. 2012. Efficacy of different fungicides for the control of downy mildew of onion. Opes Access Scientific Reports, 1 (6): 331.

2. Ascard J., Hatcher P. E., Melander B., Upadhyaya M. K. 2007. Thermal weed control. Non-chemical Weed Management, p. 155-175. https://doi.org/10.1079/9781845932909.0155

3. Braziené Z., Vasinauskiené R. 2016. Damp water steam influence on weeds and foliar fungal diseases in sugar beet crop. Fresenius Environmental Bulletin, 25 (7): 2654-2661.

4. Cederlund H., Börjesson E. 2016. Hot foam for weed control - Do alkyl polyglucoside surfactants used as foaming agents affect the mobility of organic contaminants in soil. Journal of Hazardous Materials, 314: 312-317. https://doi.org/10.1016/j.jhazmat.2016.04.061

5. Datta A., Knezevic S. Z. 2013. Flaming as an alternative weed control method for conventional and organic agronomic crop production systems: a review. Advances in Agronomy, 118: 399-428. https://doi.org/10.1016/B978-0-12-405942-9.00006-2 
6. De Cauwer B., Bogaert S., Claerhout S., Bulcke R., Reheul D. 2014. Efficacy and reduced fuel use for hot water weed control on pavements. Weed Research, 55 (2): 195-205. https://doi.org/10.1111/wre.12132

7. Edesi L., Jarvan M., Adamson A., Lauringson E., Kuht J. 2012. Weed species diversity and community composition in conventional and organic farming: a five-year experiment. Zemdirbyste-Agriculture, 99 (4): 339-346.

8. Fontanelli M., Raffaelli M., Ginanni M., Lulli L., Frasconi C., Sorelli F., Peruzzi A. 2009. Non-chemical weed control on open-field fresh market tomato in the Serchio Valley (Central Italy). Proceedings of $8^{\text {th }}$ EWRS Workshop and Physical and Cultural Weed Control. Zaragoza, Spain, p. 41-48.

9. Jodaugienė D., Raudonius S., Špokienė N. 2008. Piktžolių ekologija. Lithuanian University of Agriculture, 108 p. (in Lithuanian).

10. Kerpauskas P., Sirvydas A. P., Vasinauskienè R., Tamošiunas A. 2009. Influence of thermal effect duration on onion yield. Agronomy Research, 7 (spec. iss. 1): 323-327.

11. Marcinkevičienè A., Velička R., Butkevičienė L. M., Keidan M., Pupalienė R., Kriaučiūnienė Z., Kosteckas R., Čekanauskas S., Raudonius S. 2018. The impact of nonchemical weed control methods on the disease occurrence in the organically grown winter oilseed rape crop. Zemdirbyste-Agriculture, 105 (4): 331-338. https://doi.org/10.13080/z-a.2018.105.042

12. Melander B., Kristensen J. K. 2011. Soil steaming effectson weed seedling emergence under the influence of soil type, soil moisture, soil structure and heat duration. Annals of Applied Biology, 158: 194-203. https://doi.org/10.1111/j.1744-7348.2010.00453.x

13. Pannacci E., Tei F. 2014. Effects of mechanical and chemical methods on weed control, weed seed rain and crop yield in maize, sunflower and soyabean. Crop Protection, 64: $51-59$

https://doi.org/10.1016/j.cropro.2014.06.001

14. Rasiukevičiūtė N., Supronienè S., Valiuškaitè A. 2016. Effective onion leaf fleck management and variability of storage pathogens. Open Life Sciences, 11: 259-269. https://doi.org/10.1515/biol-2016-0036

15. Raudonius S. 2017. Application of statistics in plant and crop research: important issues. Zemdirbyste-Agriculture, 104 (4): 377-382. https://doi.org/10.13080/z-a.2017.104.048

16. Shrestha A., Moretti M., Mourad N. 2012. Thermal and organic weed control herbicide evaluation dirty almond (Prunus dulcis) gardens. Weed Technology, 26 (1): 110-116. https://doi.org/10.1614/WT-D-11-00083.1

17. Shrestha A., Kurtural S. K., Fidelibus M. W., Dervishian G., Konduru S. 2013. Efficacy and cost of cultivators, steam or an organic herbicide for weed control in organic vineyards in the San Joaquin Valley of California. HortTechnology, 23 (1): 99-108.

https://doi.org/10.21273/HORTTECH.23.1.99

18. Sirvydas P. A., Kerpauskas P. 2012. Terminis piktžolių naikinimas: monografija. Aleksandras Stulginskis University, p. 258-268 (in Lithuanian).

19. Sivesind E. C., Leblanc M. L., Cloutier D. C., Seguin P., Stewart K. A. 2012. Impact of selective flame weeding on onion yield, pungency, flavonoid concentration and weeds. Crop Protection, 39: 45-51.

https://doi.org/10.1016/j.cropro.2012.03.009
20. Southwood M. J., Viljoen A., McLeod A. 2015. Inoculum sources of Fusarium oxysporum f. sp. cepae on onion in the Western Cape Province of South Africa. Crop Protection 75: 88-95.

https://doi.org/10.1016/j.cropro.2015.05.014

21. Ulloa S. M., Datta A., Knezevic S. Z. 2010. Growth stage influenced differential response of foxtail and pigweed species to broadcast flaming. Weed Technology, 24: 319-325. https://doi.org/10.1614/WT-D-10-00005.1

22. Ulloa S. M., Datta A., Bruening C., Gogos G., Arkebauer T. J., Knezevic S. Z. 2012. Weed control and crop tolerance to propane flaming as influenced by the time of day. Crop Protection, 31 (1): 1-7. https://doi.org/10.1016/j.cropro.2011.09.005

23. Valiuškaitė A., Uselis N., Survilienė E. 2010. Investigation of iMETOS ${ }^{\circledR} \mathrm{sm}$ Botrytis spp. prediction model in strawberries. Sodininkystè ir daržininkystè, 29 (3): 13-21 (in Lithuanian).

24. Van der Weide R., Bleeker P., Achten V., Lotz L., Fogelberg F. Melander B. 2008. Innovation in mechanical weed control in crop rows. Weed Research, 48: 215-224. https://doi.org/10.1111/j.1365-3180.2008.00629.x

25. Velička R., Marcinkevičienè A., Pupalienè R., Butkevičienè L. M., Kosteckas R., Čekanauskas S., Kriaučiūnienė Z. 2016. Winter oilseed rape and weed competition in organic farming using non-chemical weed control. Zemdirbyste-Agriculture, 103 (1): 11-20. https://doi.org/10.13080/z-a.2016.103.002

26. Virbickaitė R., Sirvydas P. A., Kerpauskas P., Vasinauskienè R. 2006. The comparison of thermal and mechanical systems of weed control. Agronomy Research, 4: 451-455.

27. Vidotto F., De Palo F., Ferrero A. 2013. Effect of shortduration high temperatures on weed seed germination: high temperatures affecting weed seeds. Annals of Applied Biology, 163:454-465. https://doi.org/10.1111/aab.12070

28. WRB. 2014. World reference base for soil resources. World Soil Resources Report 106. FAO, Rome, p. 187-189.

29. Wszelaki A. L., Doohan D. J., Alexandrou A. 2007. Weed control and crop quality in cabbage (Brassica oleracea (capitata group)) and tomato (Lycopersicon lycopersicum) using a propane flamer. Crop Protection, 26 (2): 134-144. https://doi.org/10.1016/j.cropro.2006.04.012

30. Žemès ūkio augalų kenkejjai, ligos ir jų apskaita. $2002 /$ compiled by Šurkus J., Gaurilčikienė I. Lithuanian Institute of Agriculture, 346 p. (in Lithuanian). 
ISSN 1392-3196 / e-ISSN 2335-8947

Zemdirbyste-Agriculture, vol. 106, No. 1 (2019), p. 53-58

DOI 10.13080/z-a.2019.106.007

\title{
Vandens garų poveikis piktžolėms ir grybinẻms ligoms svogūnų pasèlyje
}

\author{
R. Vasinauskienè ${ }^{1}$, Z. Brazienè ${ }^{2}$, D. Avižienytè ${ }^{2}$ \\ ${ }^{1}$ Vytauto Didžiojo universiteto Žemès ūkio akademija, Lietuva \\ ${ }^{2}$ Lietuvos agrarinių ir miškų mokslų centro Rumokų bandymų stotis
}

\section{Santrauka}

2012 m. Kauno rajono, 2013 m. Vilkaviškio rajono ir 2014 m. Rietavo savivaldybès ūkininkų laukuose buvo atlikti tikslieji lauko bandymai, siekiant nustatyti vandens garų kaip terminès kontrolès įtaką piktžolėms ir grybinėms ligoms valgomojo svogūno (Allium cepa L.) pasèlyje. Tyrimas buvo atliktas pagal schemą: 1) piktžolès ravètos rankomis tris kartus; pirmą kartą ravèta piktžolėms masiškai sudygus, 9-11 d. po sodinimo; pakartotiniai antras ir trečias ravëjimai buvo atlikti piktžolėms sudygus, 2-3 lapelių augimo tarpsniu; 2) piktžolès naikintos drègnuoju vandens garu du kartus per vegetacijos periodą, drègno vandens garo aplinkos išlaikymo trukmè - 2 sekundès; piktžolių terminis naikinimas buvo vykdytas ištisai visame laukelyje, svogūnų neapsaugant nuo drègno vandens garo poveikio; 3) piktžolès naikintos drègnu vandens garu du kartus per vegetacijos periodą, drègno vandens garo aplinkos išlaikymo trukmè - 2 sekundès; piktžolių terminis naikinimas vykdytas tik tarpueiliuose, joms esant daigo tarpsnio, o svogūnų ropelèms drègno vandens garo poveikis buvo dalinis.

Tyrimo duomenimis, svogūnų pasėlyje piktžoles efektyviausiai naikino vandens garai, panaudoti du kartus ištisinio plikymo būdu. Vandens garai mažino svogūnų sergamumą grybinėmis ligomis. Netikrosios miltligės intensyvumas laukeliuose, kuriuose buvo panaudoti vandens garai, sumažèjo 52,5-73,9 \%, lyginant su kontroliniais laukeliais. Vandens garus panaudojus ištisiniu būdu, sklerotinio puvinio pažeidimų sumažèjo 43,5-46,9 \%. Vandens garai, panaudoti pasėlyje ištisiniu būdu, svogūnų sergamumą kekeriniu puviniu sumažino $68,0-86,1 \%$, panaudoti tarpueiliuose - 33,3-83,7 \%. Tyrimo duomenimis, svogūnų ropeliu derlius svyravo nuo 4,06 iki 5,41 kg m². Laukeliuose, kurie buvo ištisai purkšti vandens garais, gautas esmingai didesnis svogūnų derlius nei ravètuose.

Reikšminiai žodžiai: Allium cepa, miltligè, piktžolès, pilkasis puvinys, svogūnų derlius, vandens garai. 